\title{
Democracy in Islam: comparative study of Muhammad Abid al-Jabiri and Abdolkarim Soroush's thoughts
}

\author{
Happy Susanto \\ University of Proklamasi 45 Yogyakarta, Indonesia \\ E-mail:hpysusanto@yahoo.co.id
}

\begin{abstract}
Using analytic and interpretative approaches, this research compares al-Jabiri and Soroush's thoughts about democracy in Islam. To assess Islam's compatibility with democracy, this thesis will analyze the issues of authority, sharia, and freedom according to the two scholars. Al-Jabiri and Soroush agree that the concept of authority in Islam cannot be interpreted simply as God's sovereignty, but it also concerns human rights and sovereignty. A leader put justice as his/her central concern in practicing policies for citizens. To pursue this hope, they also propose that sharia should be reinterpreted in order to be harmonizing in accordance changing circumstances and time. Al-Jabiri has different understanding with Soroush about the relationship between religion and state. Al-Jabiri sees that Muslims are free to choose democracy as their political life. He doesn't agree the integration of religion and state. In this case, he doesn't agree the implementation of sharia in the state. Meanwhile Soroush sees that religion has an important role in the state, so that he agrees the implementation of sharia because according to him it supports the political process of the state.
\end{abstract}


Muhammad Abid al-Jabiri dan Abdolkarim Soroush merupakan intelektual Muslim yang memandang bahwa Islam kompatibel dengan demokrasi, dan keduanya termasuk dalam kelompok moderat. Untuk menguji apakah Islam kompatibel dengan demokrasi, artikel ini menganalisis isu-isu otoritas, syariah, dan kebebasan menurut pandangan kedua tokoh tersebut. Kedua intelektual itu memiliki pandangan filosofis yang sejalan tentang ide demokrasi dalam Islam. Misalnya, konsep otoritas dalam Islam tidak saja dipahami sebagai bentuk kedaulatan Tuhan, namun yang lebih penting bahwa konsep ini juga memerhatikan aspek hak dan kedaulatan manusia. Syariah perlu direinterpretasi agar sesuai dengan konteks perubahan zaman dan dapat mengarah pada pencapaian tujuannya. Perbedaan keduanya terletak pada relasi agama-negara. Dalam hal ini, al-Jabiri memiliki pandangan yang "liberal" bahwa konsep sebuah negara tidak perlu berdasarkan identitas agama. Umat Islam diberikan kebebasan penuh untuk menjalankan kehidupan politiknya, tanpa terbebani oleh rujukan teks-teks Islam yang masih diperdebatkan. Dengan demikian, ia memandang bahwa penerapan syariah dalam sebuah negara tidak perlu karena sesungguhnya syariah belum penah diterapkan secara sempurna. Sedangkan Soroush berpandangan sebaliknya bahwa identitas agama perlu ditambatkan ke dalam ide sebuah negara (demokrasi).

Keywords: Islam; Democracy; Authority; Freedom; Sharia

\section{Introduction}

The discourse about the relationship between Islam and democracy has long been a hot debate in the Muslim world. Since decay in 1980, democracy became the trend which has been studied by many scholars of world politics. A lot of recent studies about the relationship between Islam and democracy, as have been done by Samuel P. Huntington and Francis Fukuyama, give negative assessments by having the notion that Islam is not compatible with democracy. ${ }^{1}$ Their views rely on a number of Islamic teachings which are assumed to be contrary with democracy.

\footnotetext{
${ }^{1}$ Bahtiar Effendy, Teologi Baru Politik Islam: Pertautan Agama, Negara, dan Demokrasi, Yogyakarta: Galang Press, 2001, 108-109.
} 
However there are a number of Western writers who assess this phenomenon positively, for example John L. Esposito and John O. Voll who see that in various regions in the world, religious resurgence movements can cooperate and sometimes actually strengthen to the forming of democratic political systems. About the phenomenon that happened in Muslim world, they argue that these issues are emerging to the surface because of Islamic resurgence and the demands of the people for participation in the political process. ${ }^{2}$ They point to the Iranian Islamic revolution in 1979 and also to the forming of Front of Islamic Salvation (FIS) in Algier in the early of 1990 as forms of Islamic resurgence that demand democratic political process.

Questions about the relationship between Islam and democracy emerge when Islam deals with the actual problems of the challenge of modernity. There are two tendencies that emerge when tradition deals with modernity; the tendency of liberalism and the tendency of conservatism. The first tendency accepts modernity as a consequence of epoch change, so that the progressiveness in modernity should be appreciated and interfaced with the tradition, meanwhile the second tendency confirms the tradition as a single solution which is able to overcome various problems, without the necessity to use rational and modern approaches.

Is Islam compatible with democracy? To answer this matter requires a deep study of Islamic tradition that discusses democracy. Islam, in fact, has a set of symbols and concepts which support freedom and equality as principles of democracy, although there are also aspects of absolutism and a hierarchical power system. Esposito and

2 John L. Esposito and John O. Voll, Islam and Democracy, Oxford and New York: Oxford University Press, 1996, 3. 
Voll affirm that it is very important to research the conceptual sources of Islamic tradition discussing democracy. ${ }^{3}$

The study of democracy related with the religious tradition has been done by two famous Muslim intellectuals, Muhammad Abid al-Jabiri and Abdolkarim Soroush. Al-Jabiri is a Muslim intellectual from Morocco who is recognized for his mega-project, " a critique of Arab reason" (naqd ' aql al-'Arabi i), while Soroush is a Muslim intellectual from Iran who is recognized as a person who very persistently calls for the development of rational thought, freedom, and democracy in Muslim world.

This paper takes the thoughts of Muhammad Abid al-Jabiri and Abdolkarim Soroush as a comparative study about democracy in Islam. These thinkers are selected because they are representatives as Muslim intellectuals from Arab and non-Arab regions, also from Islamic traditions of Sunni and Syiah. Al-Jabiri represents the first tradition and region, while Soroush represents the second.

Al-Jabiri is known as one of the progressive Muslim intellectuals who did many critical studies about tradition and modernity, also called upon the importance of developing the democratic life order in Arab nations. Al-Jabiri did many critical studies about epistemology of Islamic thought and political practices of Sunni Islam. Meanwhile Soroush is known as a liberal Muslim intellectual from Iran who did many critical studies of Syiah tradition, and also intensively studied the issue of democracy in Islam with rational approaches. Both figures adequately represent the two traditions of Islamic thought.

The Muslim world nowadays experiences immeasurable conflicts among the supporters of elite political groups. The ruling elite group tries to develop its influence by forming institutions which are capable

${ }^{3}$ John L. Esposito and John O. Voll, Islam and Democracy,7. 
of improving its interests. ${ }^{4}$

Al-Jabiri affirms that democracy is a historical necessity required for Arab society at this time. This statement relied on the inexistence of democracy and civil society in all Arab states, as well as non-institutional states which are supported by independent institutions belonging to these states. ${ }^{5}$ Soroush also affirm the importance of democracy in the Muslim world. One of the principles of democracy is the demand to create the structural justice. Justice is a heritage of the Islamic tradition which is often forgotten in creating the better political order. ${ }^{6}$

Among issues which are often disputed in discussing the compatibility of Islam and democracy are issues about authority, sharia, and freedom in Islam. This thesis takes these issues in order to test whether Islam can be compatible with democracy. These three issues are crucial problems which are still to be source of controversy and debate among Muslims. Therefore, this thesis tries to study the mentioned issues to find a framework for thinking about democracy in Islam which is acceptable in the Muslim world.

The problems in this study are: Firstly, how the relationship between Islam and democracy according to al-Jabiri and Soroush? Secondly, how far the compatibility between Islam and democracy according to them by making the issues of authority, sharia, and freedom in Islam as tools of the test?

\footnotetext{
${ }^{4}$ Muhammad Abid Al-Jabiri, "Problem Demokrasi dan Civil Society di Negara-Negara Arab", in Mun'im A. Sirry (ed.), Islam, Liberalisme, Demokrasi: Membangun Sinergi Warisan Sejarah, Doktrin, dan Konteks Global, Jakarta: Paramadina, 2002, 250-251.

5 Muhammad Abid Al-Jabiri, "Problem Demokrasi dan Civil Society di Negara-Negara Arab", 233.

${ }^{6}$ Abdolkarim Soroush, "Mencari Format Ideal Hubungan Islam dan Demokrasi", in Mun'im A. Sirry (ed.), Islam, Liberalisme, Demokrasi: Membangun Sinergi Warisan Sejarah, Doktrin, dan Konteks Global, Jakarta: Paramadina, 2002, 136-137.
} 


\section{Compatibility between Islam and democracy}

Intellectual Muslims respond to democracy in various ways, there are those who see compatibility between Islam and democracy, but there are also those who refuse it. Conceptually, values in democracy have been stated in special aspects of Islamic tradition that converse about political and social problems. For example, the Islamic concept about deliberation (shūrā), consensus (ijmā'), and an independent interpretation (ijtihād) have an important role in the discourse and debate about democratization in the Muslim world. ${ }^{7}$

Muslim Intellectual responses to democracy are mapped by Clinton Bennett into two spectrums, left and right. ${ }^{8}$ The right spectrum is categorized as nomocracy that positions an elite ruler as the single valid power holder in traditional sharia. This spectrum is filled with fundamentalists and revivalists. In the first group, the leader is not chosen through an election mechanism, the sharia view is traditional, and rulers collaborate with the traditional Muslim scholars. While in the second group, a leader is selected through an election mechanism, but minorities and women are discriminated in the election process. Sharia is interpreted traditionally, especially in dealing with gender and punishments such as cutting off the hands of some criminals. The view of pluralism is also limited because only practices the state with just one party. This group is represented by al-Maududi.

The second spectrum is filled by progressive and secular groups. The first group has some agreements with revivalism because they agree with the concept of an Islamic state. But, their view of sharia is reformative (progressive) and their view of civic rights is open (plural-

7 John L. Esposito and John O. Voll, Islam and Democracy, 27.

${ }^{8}$ Clinton Bennett, Muslims and Modernity: An Introduction to the Issues and Debates, London: Continuum, 2005, 44-45. 
ism), so they do not discriminate against minority and women's rights. Their view on pluralism is lenient because they support multi-party systems and democratic states. Bennett writes that this group is represented by Mahmud Thaha. Al-Jabiri can also be categorized in the progressive group because in addition to holding pluralist views, he promotes the project of Islamic resurgence and opposes the concept of secularism. The second group (secular) argues for the necessity of separation between religion and politics. Islam can submit the messages of public ethics or morals in a state, but does not have the authority of law. Fatimah Mernissi, Fuad Zakariya, Bassam Tibi, and Soroush are in this group.

Al-Jabiri has an interesting view in seeing the compatibility of Islam and democracy. Al-Jabiri studies this problem by comparing the meaning "democracy" in the views of tradition authority (Islam) and authority of the European renaissance.

In tradition authority, the model of the governance of shūrā is a governance conducted by "a just autocrat", which is represented by a figure of Umar Bin Khattab. According to al-Jabiri, shūrā functioned as a "fastener" for power so that it can be protected from brutality. Before conducting action, the ruler is suggested to do the process of consultation or deliberation (shūrā ) with ahl al-hall wa al-'aqd, Muslim scholars, fuqaha, and prominent persons of society.

Shürā do not fasten the power. Even though the ruler conducts the consultation process, the final decision remains in the hands of the ruler. The shūrā is independent from government institutions because shūrā means "taking something from its place, that is from somebody whom his opinion is taken". His opinion does not automatically have to be followed because shürā is not binding. Besides that, if the opinion is accepted responsibility for the decision still has to be shouldered by the ruler. 
Al-Jabiri argues that democracy differs from shūrā. The reason is that historically the emergence of democracy differs from the concept of shürā which is known in Islam. According to al-Jabiri, in the system of authority of the Renaissance when European democracy first emerged, was historically; interconnected with the ruination of the power system that was monopolized by the leader of a tribe. It was replaced with the phenomenon of civil society and the idea of the citizen, which emerged first in Greece and Rome. ${ }^{9}$

In the $17^{\text {th }}$ century, the conflict against tyranny expanded along with the appearance of civil powers and merchant groups (bourgeoisie) who struggled for democracy. Democracy in this meaning is the form of governance through a free election process, transparency, and power which was divided into executive, legislative, and judicial branches. The development of democracy did not happen in the history of Islam. Power in Islam is formed with the single power character. Chosen ruler seldom be conducted through process of bay'at (election by some important persons), but often happened through strength and domination.

Therefore, democracy is unlike shūrā. Al-Jabiri's approach to interpreting the relationship between religion (shürä) and democracy like that very influenced by Ibnu Rusyd's thought in seeing the relationship between religion and philosophy. Ibnu Rusyd emphatically says that philosophy is different from religion because philosophy uses the demonstrative method (burhānï reason) in searching truth, while religion (Islam) follows the sources of Quranic verses and haditht. But, Ibnu Rusyd says that it doesn't mean that both are incompatible, and in fact each can complement the each to come near the truth. Even, Ibnu Rusyd hopes that Muslims want to use the philosophy to compre-

9 Muhammad Abid Al-Jabiri, Syura: Tradisi, Partikularitas, dan Universalitas, trans., Mujiburrahman, Yogyakarta: LKiS, 2003, 31. 
hend the religion because mind (rationality) is a tool to comprehend religion and God.

With the same tone, al-Jabiri sees that even democracy is conceptually different from the shūrā, but both can meet each other to realize the just governance. According to religion's viewpoint, the problem of democracy represents "unthinkable" (allā mufakkar fih) issue in Islamic tradition. The methods of politics and state were thought (al-mufakkar fih) in the reference of Islamic tradition is the concept of shürā. For this reason, Muslims allowed to take democracy as a method and a tool to do political action.

Al-Jabiri affirms that democracy undoubtedly must be selected by Arab societies in this time as a step in the transition to a better political life. He expects democracy to overcome the problems of political conflict that have blanketed Arab nations for years. ${ }^{10}$

Al-Jabiri's approach that is based on historical analysis about religion and democracy differentiates him from Soroush who concentrates on epistemological analysis in understanding the relationship between Islam and democracy, without first examining the historical construction of both conceptions. It means that, epistemologically, democracy is not different from the political method in Islam. Soroush sees rational aspects of religion which can support the acceptance of democracy as a very important concept in Islamic governance.

Soroush raises the objective opinion and concept about the reconciliation of Islam and democracy. Soroush gives the idea of "religious democratic governance" as a synthesis of Islam and democracy. Soroush maps the principles which are implied in the concept of religious democratic governance. ${ }^{11}$ Firstly, the reconciliation of religion and

\footnotetext{
10 Muhammad Abid Al-Jabiri, Syura: Tradisi, Partikularitas, dan Universalitas, 37.

${ }^{11}$ Abdolkarim Soroush, Reason, Freedom, and Democracy in Islam: Essential Writings of
} 
democracy assessed by Soroush as an example of the compatibility of religion and reason. Reason is so central in growing religious democracy. As Soroush says, a prerequisite to the democratization of religious governance is using historical context and empowering the understanding of religion that emphasizes the role of reason. The intended reason is a collective one which emerges from public participation and human experience in using democratic method.

The second principle mentions that the reconciliation of religion and democracy shows the intelligence of meta-religious artifice which has the epistemology of extra-religious dimension. It means that religion talks about "democracy". Its intention, the problem of democracy includes the object of Islamic thought and study. Thirdly, religious understanding has to adapt to the fact that democracy has succeeded in limiting power, achieving justice, and getting human rights. It means that religion has to accept these achievements in order to understand and accept democracy. Fourthly, the right of arbitration (problem solving) is delivered to the dynamic public wisdom which has relation with religion. Fifth, understanding that religion changes, has a rational character, and is in harmony with common criterion of non-religious is accepted to decide the issues of religious democratic governance. Sixth, without a religious society, religious democratic governance cannot be conceived.

\section{Issues of democracy in Islam}

\section{Authority}

The issue of authority opens a long discussion about "God's sovereignty" (hakimiya Allāh) and "democracy" (hakimiya al-nās) in Soroush's

Abdolkarim Soroush, ed. Mahmoud Sadri and Ahmad Sadri, Oxford and New York: Oxford University Press, 2000, 131-132. 
understanding of the possibility of synthesis between the two concepts. Given this problem, Soroush gives the idea of "religious democratic governance" as an answer for the reconciliation between God's sovereignty and democracy, it means that the religious governance can take democracy as one of political guidance. According to Soroush, this idea undertakes three things, (1) to connect people's satisfaction and God's blessing; (2) to balance the businesses of religion and nonreligion; and (3) to do right to people as well as to God, by confessing the existence of human beings and religion. ${ }^{12}$

But, Soroush's view about authority issue more concentrates on giving some important criticisms toward the concept of secularism, which is often assumed only to promote human desire by dismissing the role of God. He criticizes the secular view that in the system of secular society, the concept of religious democratic governance is not possible to apply. Secular groups assume that religious governance cannot be justified to people, because it can only be justified to God. Meanwhile, Soroush notes that purely secular governance has not yet been proved to have a democratic character. A governance is told as democratic system when the principles of democracy applied in the state.

For Soroush, a regime of religion can be considered democratic if it fulfills two conditions, which are (1) how far religious governance has full role in taking a hand in state collective policy, and (2) how far governance respects human rights. ${ }^{13}$ Thereby, the religious democratic governance should be able to harmonize God's expectations and satisfaction as well as human being's at one blow, by making issues of

\footnotetext{
${ }^{12}$ Abdolkarim Soroush, Reason, Freedom, and Democracy in Islam: Essential Writings of Abdolkarim Soroush, 123.

${ }^{13}$ Abdolkarim Soroush, Reason, Freedom, and Democracy in Islam: Essential Writings of Abdolkarim Soroush, 126.
} 
human right as an integral part of the process of decision making because religion gives a clear definition of what human beings are and what rights they have.

Meanwhile, al-Jabiri sees that authority issue is not released from the discussion about "khalifah" (leader) and "khiläfah" (leadership). Discussion of both covers respective things about the process of electing leader, power limitation, and the extent of sovereignty. This discussion is important because in the Sunni political system, khalifah is a holder of power to fulfill God's rights and expectations. In Syiah tradition, the concept of khalifah is unknown but similar to the term imamah, which is the leadership members (imām) of the Prophet's clan. The issue of imamah is missing from Soroush's analysis, because he speaks at the philosophical level, which means the epistemological perspective in questioning the relation between God's rights and human being's rights.

How do Islamic thinker see the problem of khalifah? In Sunni tradition, the historical framework of the meeting of Muhajirin and Anshar in Saqifah Bani Saidah after the death of the Prophet is a special reference (ïthār marja'i ra'îsî) in determining khalifah. According to al-Jabiri, debates happening at that time represent the pure political debate. ${ }^{14}$ The political strength was a solver of conflict problem at that time.

In Islamic history, it has been happened the "the lack of legislation" (no references) which arrange detailed things about leader election and power limitation. A question which must be raised in this case is: what political system will be able to compromise with this time and to answer the challenge of this epoch? The slogan "Islamic solution" and "Islamic orientation" really are only slogans, without meaning..$^{15}$ The problem of

${ }^{14}$ Muhammad Abid Al-Jabiri, Agama, Negara, dan Penerapan Syariah, trans. Mujiburrahman, Yogyakarta: Fajar Pustaka Baru, 2001,13.

${ }^{15}$ Muhammad Abid Al-Jabiri, Agama, Negara, dan Penerapan Syariah, 71. 
politics, in fact is an earthly problem, as explained by the Prophet: "You know more about your earthly business". Tradition supports the study of ijtihad (thought) which tries to comprehend the political context of this time with the historical viewpoint. According to al-Jabiri, by making "goodness" (mașlaḥah) as a reference, Islamic ethics as a conductor, and historical experience as a domain to take lesson from, so these things will indicate that the political chaos at a sahaba period as an expression of the lack of jurisprudence about government system. ${ }^{16}$

The lack of Islamic jurisprudence about political governance of Muslims, according to al-Jabiri, is because of three main problems. ${ }^{17}$ Firstly, the lack of a method in choosing khalifah. The Prophet never gave a frame of reference in religious texts about who would continue his leadership. Abu Bakar was chosen as the first khalifah as a result of ijtihad, and it represented a hurried decision for the sake of political stability at that moment, which also happened in the selection of 'Umar, Uthman, and 'Ali. Al-Jabiri says that since there is no special method for electing khalifah that door remains open for ijtihad and any alternative possibility. Secondly, the lack of limitation of khalifah's period. Initially, the duty of khalifah was to lead the jihad against the apostates and various conquests. Logically, if wartime ended the khalifah would have to release his position and becomes an ordinary society member. Since there is no explicit text about this issue, the model used is "amir" a person commisioned as a troop commander. Thirdly, the lack of limitations on power of the khalifah. According to al-Jabiri, the problem of authority limitation is "an unthinkable" (ghayr al-mufakkar fih) issu because that period was a time of conquest, war, regional extension, and internal political turbulence.

\footnotetext{
16 Muhammad Abid Al-Jabiri, Agama, Negara, dan Penerapan Syariah, 72-73.

17 Muhammad Abid Al-Jabiri, Agama, Negara, dan Penerapan Syariah, 73-79.
} 
Al-Jabiri's view on the authority issue gives the conclusion that actually the concepts of khalifah and power represent the ijtihad of human beings in doing their political activities. So that, collision between God's and human's rights easily can be avoided because Islamic references give full freedom for Muslims to do their political activities. From alJabiri's long explanation about political conditions in the early period of Islam, I see that al-Jabiri's view about the concept of authority is made him focus on the acceptance of religion to human rights.

\section{The issue of sharia}

Charles Kurzman notes that there are three models of liberal reading of sharia. ${ }^{18} \mathrm{~A}$ first model is liberal sharia. This first model says that sharia is itself actually liberal. This group sees the importance of seeking authenticity by making liberal positions based on the sources of Islam (al-Quran and Hadith).

Second model is silent sharia. This model notes that sharia does not give clear answers about certain topics and does not talk about more contemporary issues. One such issue is the question: does Islam talk about a governance system? This group remains based on Quranic interpretation (tafsir) to form the ultimate mind, but they have the lesser burden because they do not seek to find explicit proof for their positions in its texts. Its reason, they assume that sharia does not regulate all human being problems. This group assumes that sharia more talks about moral and spiritual problems, rather than the problems of social and political life.

The third liberal reading model is an interpreted sharia. Kurzman argues that this model is liberal because it holds the notion that sharia is

${ }^{18}$ Charles Kurzman, "Introduction: Liberal Islam and Its Islamic Context", in Charles Kurzman (ed.). Liberal Islam: A Sourcebook, New York and Oxford: Oxford University Press, 1998, 13-18. 
mediated by human interpretation. This group assumes that sharia must be reinterpreted. They see sharia as divine, while interpretation is human and can be filled by confusion, difference, and conflict (opposition).

Soroush's view on sharia is near to the understanding model of the interpreted sharia group in seeing the importance of interpreting religious texts. The challenges of the interpreter's epoch influence how the interpreter interprets sharia. This life cannot be separated from two different sides, are religious and extra-religious problems. Praying, revelation, belief, and religious values are considered problems related to religion, whereas free will, democracy, and human rights are considered as outside of religious problems. However, these outside problems actually influence internal religious ones.

Soroush's reading of religion (sharia) uses "evolution and devolution of religious knowledge" which separates "religion" and "religious knowledge". ${ }^{19}$ The purpose of this theory is to give the detailed explanation in the process of comprehending religion, and its conclusion is that the process experiences change. This means, the process of human understanding can fluctuate depending on conditions.

The theory sees religious knowledge as a branch of human knowledge, and assumes that the human understanding toward religion will evolve with other branches of human knowledge. The theory of interpretation is summarized by Soroush himself as: (1) religion, or revelation for that matter is silent (passive); (2) religious knowledge is relative, that is, relative to presuppositions; (3) religious knowledge is age-bound, because presuppositions are; (4) revealed religion itself may be true and free from contradictions, but the religious knowledge is not necessarily so; (5) religion may be perfect or comprehensive,

${ }^{19}$ Abdolkarim Soroush, Reason, Freedom, and Democracy, 33. 
but not the religious knowledge; and (6) religion is divine, but its interpretation is thoroughly human and this-worldly. ${ }^{20}$

Soroush's view on religion gives the conclusion about sharia, that it is religious knowledge itself. Sharia is a result of human understanding of religious doctrine, which contains comprehensiveness and its insufficiency, truth and its mistake. So that, sharia must be contextualized because it relates to the context of the time period that influences human understanding of religion.

Meanwhile, al-Jabiri also sees the importance of reinterpretation of sharia. Al-Jabiri can be categorized as a supporter of interpreted sharia. Al-Jabiri's thought framework about sharia based on a principle of "common goodness" (al-mașlaḥah al-'ämmah), whether obtaining the goodness itself (mașlahah) or refusing to endanger things (madharah). According to al-Jabiri, goodness is the purpose of sharia. Three ultimate pillars that determines law of sharia, are: abolition (naskh), causes of Quranic revelation (asbāb al-nuzūl), and the purpose of sharia (maqāșid al-shari'a). ${ }^{21}$ As the purpose of sharia means divided into three types of goodness, are: elementary (darūriyyāt), suplementary (hạjjìyyāt), and complementary (tahsininiyyāt). ${ }^{22}$

Furthermore, al-Jabiri explains that the relationship between laws of sharia and the three pillars has been practiced by sahaba (friends) when Muhammad still lived. Sahaba often submitted their opinions to the Prophet about goodness of law, and He accepted the opinions.

Al-Jabiri's view on sharia has been influenced by al-Syatibi who is known as a thinker in the field of methodology of ijtihad (thinking). AlJabiri says that someone who comprehends the opinion of Syatibi will

\footnotetext{
${ }^{20}$ Abdolkarim Soroush, "The Evolution and Devolution of Religious Knowledge", in Charles Kurzman (ed.), Liberal Islam: A Source Book, New York: Oxford University Press, 1998, 245-246.

${ }^{21}$ Muhammad Abid Al-Jabiri, Agama, Negara, dan Penerapan Syariah, 36.

${ }^{22}$ Muhammad Abid Al-Jabiri, Syura, 198.
} 
note that if a sharia text opposes the common good, he will take first the common good because the religious text actually means the purpose of sharia itself ( maqāșid al-sharỉ 'a). This opinion very possibly will invite protest, because some conservative Islamic groups prefer to choose the text although literally it contrasts with the common good.

The difference between Sorouh and al-Jabiri's thought about applying sharia to the issue of democracy lies in the tendency of Soroush to include the sharia in the system of religious democratic governance. Soroush sees that sharia plays a very significant role in developing the compatibility of Islam and democracy, also strengthening the religious governance. Soroush argues that the relation between sharia and democracy is very close because opposing sharia is the same with demolishing the principles of democracy. ${ }^{23}$

On the contrary, al-Jabiri notes that applying sharia to governance (state) is not easy, so must be done carefully. This is because sharia has never been applied perfectly in Islamic history. During the period of the Prophet, sharia was not revelead all at once, but revealed and constituted over a very long time, as long as the Prophet's life. ${ }^{24}$

\section{The issue of freedom}

Soroush's view on freedom is very related to reason (rationality). Reason is a dynamic capability to think and to search for the truth, and because of this meaning humans need freedom for their the struggle of life. ${ }^{25}$

Al-Jabiri notes that Islam clearly considers freedom as a common principle based on the references of Quran and Hadith. The statement

\footnotetext{
${ }^{23}$ Abdolkarim Soroush, Reason, Freedom, and Democracy, 146-148.

24 Muhammad Abid Al-Jabiri, Agama, Negara, dan Penerapan Syariah, 196-197.

${ }_{25}$ Abdolkarim Soroush, Reason, Freedom, and Democracy, 89.
} 
like this one mentioned in Quran: "Really we offer the trust to sky and earth and also mountain, but they don't accept it because of worrying, while humans accept it..." (QS. al-Ahzāb: 72). This verse means that humans accept the trust with their full freedom (choice and decision). According to al-Jabiri, slavery basically is not allowed in Islam because the common orientation of Islamic law is based on the principle that human beings are created free. ${ }^{26}$

Soroush and al-Jabiri have the same idea that Islam respects religious freedom. Freedom to choose religion is the individual right of everyone, without constraint. In a democratic society, religious freedom is respected because democracy requires a large amount of individual freedom.

Soroush argues that religious freedom is a very essential freedom because someone who chooses religion and surrenders fully to God should be esteemed because they chose that way of life freely. ${ }^{27}$ The surrender to God truthfully (Islam) relies on a principle of freedom because humans have been awarded with a mind to take the choice responsibly. Soroush affirms that religion is not compatible with constraint. Soroush's view is based on the Quran, that is: "There is no constraint to enter the religion (Islam)" (QS. al-Baqarah: 256) and word of the Prophet Nuh: "Do we constrain you to accept it, whereas you don't like?" (QS. Hūd: 28).

Al-Jabiri's view on religious freedom is related to an issue of "apostasy", which often appeared in Islamic jurisprudence. As an example is the issue of apostasy in early Islamic history, when some Muslims didn't want to pay religious obligatory taxes for the poor (zaka). AlJabiri affirms that the law of Islamic jurisprudence about apostasy is

\footnotetext{
${ }^{26}$ Muhammad Abid Al-Jabiri, Syura, 126-127.

${ }^{27}$ Abdolkarim Soroush, Reason, Freedom, and Democracy, 96-97.
} 
not related to the issue of religious freedom, but for fighting treason against the state. Islamic jurists at that time didn't see apostasy as an individual matter of religious freedom, but as rebellion against the state. Islam specifies the freedom of human beings in faith (religion), so that humans freely embrace Islam, and Prophet has no right to constrain everyone to embrace Islam. ${ }^{28}$

\section{Conclusion}

As a conclusion, I can say that Islam is compatible with democracy, according to al-Jabiri and Soroush. According to al-Jabiri, democracy is different with shürā (the political concept of Islam). But he says that Islam has relationship with democracy because Muslims allowed to use this method for their political life. Soroush sees that Islam has relationship with democracy by stressing the function of reason (rationality) which included in both concepts.

They see the compatibility if authority is understood as a mechanism of power which fulfill human sovereignty, it means that human rights are respected in the policies of the state. To make compatibility of Islam and democracy, so that sharia must be reinterpreted in order to achieve the purposes of sharia itself, are common goods. Sharia cannot be implemented formally in the state because it will make controversy among citizens. Freedom is one of the principles of democracy, which is very intended in Islam. So that, Islam supports democracy as a mechanism of democratic governance system.

\section{Bibliography}

Bennett, Clinton. Muslims and Modernity: An Introduction to the Issues and Debates. London: Continuum, 2005.

\footnotetext{
${ }^{28}$ Muhammad Abid Al-Jabiri, Syura, 128-131.
} 
Effendy, Bahtiar. Teologi Baru Politik Islam: Pertautan Agama, Negara, dan Demokrasi. Yogyakarta: Galang Press, 2001.

Esposito, John L. and John O. Voll. Islam and Democracy. Oxford and New York: Oxford University Press, 1996.

Al-Jabiri, Muhammad Abid. Agama, Negara, dan Penerapan Sharia, trans. Mujiburrahman. Yogyakarta: Fajar Pustaka Baru, 2001.

Al-Jabiri, Muhammad Abid, "Problem Demokrasi dan Civil Society di Negara-Negara Arab", in Mun'im A. Sirry (ed.). Islam, Liberalisme, Demokrasi: Membangun Sinergi Warisan Sejarah, Doktrin, dan Konteks Global. Jakarta: Paramadina, 2002: 250-251.

Al-Jabiri, Muhammad Abid. Shūrā: Tradisi, Partikularitas, dan Universalitas, trans. Mujiburrahman. Yogyakarta: LKiS, 2003.

Kurzman, Charles, "Introduction: Liberal Islam and Its Islamic Context", in Charles Kurzman (ed.). Liberal Islam: A Sourcebook. New York and Oxford: Oxford University Press, 1998: 13-18.

Soroush, Abdolkarim, "The Evolution and Devolution of Religious Knowledge", in Charles Kurzman (ed.), Liberal Islam: A Source Book. New York: Oxford University Press, 1998: 245-246.

Soroush, Abdolkarim. Reason, Freedom, and Democracy in Islam: Essential Writings of Abdolkarim Soroush, Mahmoud Sadri and Ahmad Sadri. (eds.). Oxford and New York: Oxford University Press, 2000: 33-148.

Soroush, Abdolkarim, "Mencari Format Ideal Hubungan Islam dan Demokrasi", in Mun'im A. Sirry (ed.), Islam, Liberalisme, Demokrasi: Membangun Sinergi Warisan Sejarah, Doktrin, dan Konteks Global. Jakarta: Paramadina, 2002: 233-251. 